\title{
シンポジウム 狭心症と心筋硬塞
}

いわゆる中間型を中心として

司 会 京都大学名炇教授

前川孫二 郎

（1）中間型の概念

京都大学名罯教授

前川孫二 郎

\section{SYMPOSIUM ON ANGINA PECTORIS AND MYOCARDIAL INFARCTION \\ WITH FOCUS ON THE INTERMEDIATE TYPES \\ (1) THE CONCEPT OF THE INTERMEDIATE TYPES}

\author{
Moderater \\ Magojiro MaEkawa \\ Emeritus Professor of Kyoto Universily
}

演者は今から11年前 $(1956)^{1)}$ 福岡での本会(第 53回)と日本循環器学会(第20回) の合同シンボジ ウムで，狭心症と心筋硬塞との間にはいるいるの 名前でよばれているいるいるの型の「中間型」の あることは指摘しておいた。それから11年の今 日, 心電計の普及，冠状動脈写，特に選択性: ネ動脈写, 心筋スキャンニング 酵素や乳酸の証 明等の発達で，この狭心・硬塞の中間型の臨床は とみにその重要性を加光た，そこでWHO² 1962 年, 狭心症と心笳硬塞だけでは, 虚血性心疾患の すべてが包括せられないとして，この上に中間型 之疼痛のない虚血性心疾患, すなわ口無症状性扮 よび非特異的慢性心觔障害を加えた．

虚血性心疾患, すな⿰七冠状心疾患はその大部 分が冠状動脈硬化症による。すなわら冠状動脈硬 化性心疾患である。WHOの虚血性心疾患はこの 意味に取扱われ，したがつて神経因性にくる脈管 運動性狭心症はこれにらくまれていない
そこで中間型の定義だが，これは概念的には至 つて簡単かつ明白で，「中間型とは狭心症(労作) より重く,心筋硬塞よりは軽い」である。しかし具 体的，すなわり実地臨床では必ずしもしかく簡単 明瞭ではないしこれは狭心症が周知のように主観 症状の疾患で, 客観化が必ずしも完全ではないか らである．欧米で狭心症といえば労作狭心症のこ とである，労作あるいは興奮に際して狭心痛が扣 そい，安静または平静にか壳ると間もなく（15分 以内）狭心痛は去る。そのパターンが客観的だか らである5しかしもとより労作狭心症のみが狭 心症の全部ではないすすで狭心症の父Heberden $(1768)^{3)}$ 女安静狭心症や狭心状態のあることを指 摘している。そしてこれらの狭心症のパターンは 全体亡して学作狭心症のそれの如く客観的ではな

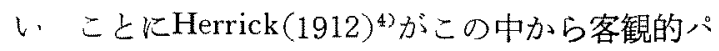
ターンの判然とした急性心筋硬塞症を分離するに 及んで，この安静時狭心症は益々正体の不明な， 
狭心症か去れとも心筋硬塞かという方充的存在上 なつた。そしてこの奴充的存在の安静狭心症こそ が今日の中間型で，WHOの定義を及ると：「労 作狭心症よりは重症であるが，今日まだ分類の不 完全ないろいろの症候群がある。たとえば安静時 に発作し，あるいは長い持続をもつ，しかしそれ 飞もかかわらず心筋垻死の証拠を欠く狭心症であ る。この委員会は目下のとこわこのグループに対 してこれ以上有用な定義や分類が可能だとは感じ ていない」まことにもつともで，特にWHOO 如き疫学を主とする立場にある際はこれで充分で あるうしかしこの定義だと中間型は確かに労作 狭心症より重症であるが，しかし心筇に壞死がな いのだから，やはり，純然たる狭心症ではなから らか、だからこれをわざわざ狭心・硬塞の中間型 とする必要はない、むしろ安静狭心症で允分であ ろらとしてこの点が中間型の定義をあいまいに するゆえんでもある，そこで中間型は何故狭心症 でも，また心矨硬塞でもないのかこの点を明白 にしなけ狄はらない，そしてここに問题の中心 がある。

そこで既述の福岡での本会シンポジウムにおい て演者の示した症例について考克てみよう

67才の男, 典型的广労作狭心症, Wa.R.(H), 安 静時心電図は軽度のS-T低下が I, II, III, $\mathrm{CR}_{5}\left(\mathrm{~V}_{5}\right)$ およびCR $\mathrm{R}_{6}\left(\mathrm{~V}_{6}\right)$ にるらる。この患者にMasterの 2 steps試験を荷すると上記のS-T低下が, 特にCR に扎いて著明になる。ところがこの同じ患者に Master試験を2 回荷すると注目すべき变化があら われる。すなわちIのS-T低下が著明となると同 時に, II, III S-Tが相反上昇 (reciprocal elevation)を示す そして $\mathrm{CR}_{2} \sim \mathrm{CR}_{5}\left(\mathrm{~V}_{2} \sim \mathrm{V}_{5}\right)$ の $\mathrm{T}$ は深い逆転波となる。この所見は急性下壁硬塞を 意味する。そこで直ちにアミール・ニトリットを 吸入させると，心電図は直ちに安静時のパターン に完全に還元した。すなわちこの際の硬塞はとの 持続が短時間だつたから，心㬳偯死を残さずに回 復したのである。このよらな硬塞の持続時間は， 条件にもよるであるらが，Blumgartら $(1941)^{5)}$
実験では20分，最近の野原ら (1967) ${ }^{6)}$ の実験で は 5〜60分といらことである。すなわちこの時間 内り心施硬塞では心㬳の機能は廃絶し, 心筋細胞 も多少の変化, 特にミトコンドリアに障害があら わ机るが，しかし完全に可逆的で，後に壊死を残 占ことなく2時間系りで回復するといら

さて以上は奏験であるが，しかしこ和で明らか なことは確かに狭心症と心筋硬塞との間に中間型 が存在し，そしてこの狭心・硬塞の中間型とは 「可逆的硬塞」つまり「䁁死のない硬塞」(infarction without necrosis) である。すなわち中間 型は硬塞という点で狭心症と，そして壊死を欠く といら点で心筫硬塞と区別される。そして正にこ の点で中間型は狭心症よりは重症で，心筋硬塞よ りは軽症となるのである。ところでこのよらな狭 心・硬塞の中間型が果して日常の臨床でみられ るだるらか すでに1937年ごろから premonitary pain(前兆疼痛) (Sampson \& Eliaser ${ }^{7}$ ), prelimin-

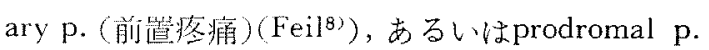
(前駆疼痛) (Brumenthal \& Reisinger, $1940^{9 j}$ )と して，「いら心゙き原园のない自発性疼痛」を切迫 せる心筋硬塞 (inpending myocordial infarction)

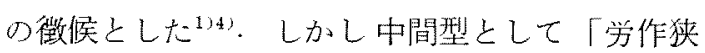
心症よりは重く急性心筋硬塞よりは軽い」と定 義したのはMaster $(1946)^{10\rangle}$ で，彼はこれを「冠 閉塞のない冠状不全」とよびそしてFreedberger, Blumgart \& Schlesinger (1948) ${ }^{11}$ に至つて初めて これを「狭心・硬塞中間型」と名付けた。Papp $(1949)^{12)}$ ○「軽怔冠状発作」(Slight coronary attack) 尼これに相当する。すなわら「心蔵痛が半 時間㐫るいはそれ以上つつき，安静時におこり， そしてtrinitrinでよくならず 常に心筋虚血の持

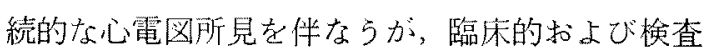
窒的には広範な心筋壊死の徴候を示さない」。 だしこに「持続的心筋虚血心電四」とあるのは 冢際は壊死を伴なわないから1週間前後で回復す る一過性のものである。

Prinzmetal $(1958)^{133} \omega\lceil$ 異型」(variant type) もこの中間型の一種で，「疼痛が昼間あるいは夜 
間の安静時または日常活動中にき，労作によつて はこない 発作時にはS-T部は一過性に，そして しばしば著明に上昇し、そして標準誘導に相反性 (reciprocal) のS-T低下がある。発作は注上んど 常に自然に終息するが，長くつうくと死亡する」. この異型で最も典型的なものは，「発作は毎日ほ とんと同じ時刻におこり,そして各発作は数10回 の反復性疼痛よりなり, 疼痛中は心電図は著明な S-T上昇と相反性S-T低下と齐標準誘導で示す。 そして疼痛が去ると 1 2 分で心電図は正常にか える、ニトログリセリンをあたえると反復性疼痛 やそ机に伴なら心電図変化を終息せしめる。そし て数力月後に心能硬塞がくるこレがあるが，その 局在は虚血時と同一である，心筋硬塞が抏こると 奇妙に直ちに心䁍痛が停止する」，彼はこれを前 硬塞(切迫性)狭心症と, その予後や病態生理の上 で区別している。すなわち部分閉塞に陥つた大き い冠動脈が機能的に，特に夜間に緊張が高まり狭 窄する (spasmodic angina).こ机に反し昼間, 特 に運動中は緊張は緩解の状態にある。これ故労作 狭心症とはならないとい5 予後は切迫性に比し 必ずしも悪くない。

己て前硬塞性狭心症型の中間型の心電図の特徵 はVakil (1960) $)^{14}$ によるると次のようである。 一見新鮮な心筇硬塞のそれに似るが，普通次の点 で区別される，(1)発作の全経過が遙が短く。 お人放数時間から数日で, 硬塞の如く数週から 数カ月に及ぶことはない（2）QR S 群が变化 に巻込まれることはない（3）ST-T部が相反 性変化を示さないで，大抵の誘導で下降性に偏位 する、すなわち92\%に扣いて浅いまたは深い缊底 様（trough-like)ST-T低下であるといら

この心電図の特徽は硬塞といらよりは虚血性の もので，特に学作狭心症におけるMasterの 2 step 試験陽性の基準と同じである．たぐしこの際は誘 発原因をもたずかつ变化の持続時間が労作時狭 心症よりは遙汃湓い（数時間乃至数日）ここ饥は

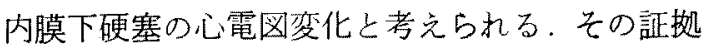
はかかる際には大抵aVRのS-T部が上昇の傾向を
みせ，典型例ではこれれが判然とした負傷流の形 をとる。乙して内膜側に直面する誘導は普通この aVRを扎いてない、しかも室内血夜のために短縮 が強い，したがつて間接的な硬塞の対面誘導によ るS-T低下が主な所見となるのであるうしたが つてかかる際硬塞巣が、心尖部内膜下にない場合 は，相反性 $\mathrm{S}-\mathrm{T}$ 偏位はaVR と前胸壁誘導 $\left(\mathrm{V}_{2} \sim \mathrm{V}_{5}\right)$ との間にくるはずでありまたVakilの症例をみて もそうである。彼のいら相反性 S-T偏位は標準誘 導にreferした際で，硬塞心電図の一般原理からい らと誤りである。またかかる中間型の硬塞巣はそ の82\%までが心内膜下にあるといわれる (Miller

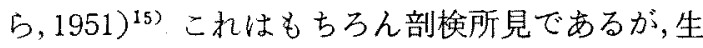
前の発作ではその心電図变化から壊死のない硬塞 であつたと思われる，切迫性心筋硬塞といわれる だけあつてVakilの例ではおよそその半数近くが 3 力月以内に真性の心觔硬塞に陥つたという し たがつてこの種の中間型も「壇死のない硬塞」と定 義して差支えないと思う。かくして「壤死のない硬 塞」は理論的にも実際的にも狭心・硬塞の中間型に 刘する簡明な定義であるとい方ようもつとも相 反性S-T低下を標準誘導に限ると前硬塞性狭心症 型の中間型にはVakilの定義が通用するであるう

結論：「狭心・硬塞の中間型」は簡明に「壊 死のない硬塞」すなわち「溒死を結果しない一時 性, 可逆的心筋硬塞」と定義するのが，理論的に も，李た実際的にも最も妥当だと思５しかしそ の臨床像は必ずしも一定しない最も普通みられ る型はいわゆる切迫性硬塞（前兆性，前硬塞性等 の疼痛, 食䭒性, 安静, 夜間等の狭心症等) で, その主症状は狭心痛であるが，この狭心痛もその 強さや持続に扣いて労作狭心症と器質的心筋硬塞 症の中間に位し，発作誘因もちよつとした労作や 興隹から，食慨，悪夢等をへて安静時自発するよ らになり，回数も次第に增加し，持続も延びる。 そして遂に狭心状態や真性の硬塞に発展する。多 くはニトログリセリンに反応せず，自然またはモ ヒで緩解する。

これに対しPrinzmetalの 異型狭心症は全く特異 
なもので，毎日同時刻，早朝安静時または昼間普 通生活時に発作し, しかも数10回の反復性狭心痛 よりなり、ートログリセりンによつてまたは自然 に緩解する。長びくと器質的硬塞にもなりまた死 亡もありらるが，多くは先の状態を長年保持し， 次第に回復する。労作時にはかえつて発作しない のが特改である。

心電図変化の特徵もまた壊死のない硬塞に相当 し，一過性可逆的の相反S-T偏位である。そして

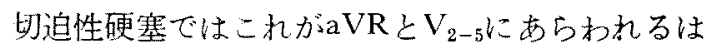
ず(内膜下硬塞)だが，aVRは室内血液による短絡 で多くの場合不明瞭となり，単純な $V_{2} \sim V_{5}$ に括け るS-T低下の観を呈する。しかし労作㹟心症上こ となりその変化の持続が長い（数時間から数日）. 異型狭心症では相反S-T偏位は標準誘道にあらわ れる，そして疼痛発作と併行し，反復出現する，

器質性硬塞でないから心蔵性虚脱, 発熱, 白血 球增多, 赤沈高度促進, 血清transaminase, LDH の上昇はない

予後：切迫性心筋硬塞は悪い早晚器質性硬 塞にいたる。これに反し異型狭心症は定常的で比 較的良好といわ玌る。しかし狭心症である限りい ずれも荤速の差こそあれ経過憔行性である。

治療：いずれ子抗凝固薬，最近はßアドレネ
ルギック容受体遮断葙の適応である。しかし最 も問题となるつは選択的シネ冠状動脈写によつ て量的診断を確定し, endoarterectomyやVineberg $(1946)^{16)}$ の内乳動脈移植術の谪応を決定するこ とであるら何故なら本疾患の経過性進行性だか らである。

\section{主要文献}

1) M. Maekawa.: Jap. Circulation J., $20:$ No. 8, 1, 1956. - 2) World Health Organization Technical Report Series No. 231. -3) Heberden, W.: Med. Trans., 2 : London, 1772. -4) Herrik, J.B.: J.A.M.A., $59: 2015,1912$. -5) Blumgart, H.L., Gilligan, R. \& Schlesinger, M.: Amer. Heart J., $22: 374,1941 .-6$ ) Y. Nohara : reported in this symposium, 1967. --7) Sampson, J.J. \& Eliaser, M.: Amer. Heart J., 13:675, 1937. 8) Feil, H.: Amer. J. med. Sci., 193:42,1937. 9) Brumenthal, B. \& Reisinger, J.: Amer. Heart J., $20: 141,1940 .-10$ ) Master, A.M.: New York Med., $2: 19,1946$. -11) Freedberger, A.S., Blumgart, A.L.: Zoll, P.M. J.A.M.A., 138 : 107, 1948. -12) Papp, C.: Brit. Heart J., 11: 411,1949. - 13) Prinzmetal, M., Kennamer, R., Merliss, R., Wada, T. and Bor, N.. Amer. J. Med., $27: 375$, 1959. - 14) Vakil, R.J.: Circulation, $24: 557,1961$. -15) Miller, R.D., Burchell, H.B. \& Edwards, J.E.: Arch. intern. Med., 88 : 597, 1951. - 16) Vineberg, A.: Ann. Surg., 159: : 185, 1964. 